YAK 347.659.1

DOI https://doi.org/10.32837/chc.v0i42.432

\author{
Чупрій АІана Юріївна, \\ магістрант Інституту права \\ Київського національного університету імені Тараса Шевченка \\ ORCID ID: https://orcid.org/0000-0002-8608-0579
}

\title{
ОКРЕМІ ПРОБЛЕМИ СУБ'ЄКТНОГО СКЛАДУ ПРАВОНАСТУПНИЦТВА В АВТОРСЬКИХ ПРАВАХ У СКЛАДІ ВІДУМЕРЛОЇ СПАДЩИНИ
}

Постановка проблеми. Реалії сьогодення Аають змогу стверАжувати, що кожна АюАина має принаймні оАиничний АосвіА самостійного створення об'єкта авторського права. Суб'єктивне авторське право виникає незалежно віА якості твору, факту його оприлюднення, рівня навичок чи професіоналізму автора: будь-який твір потенційно може становити цінність не тільки Аля самого творця, а й Аля суспільства в цілому, тому створення сприятливих умов Аля пліАного зАійснення інтелектуальної діяльності, якісне правове врегулювання правовідносин у сфері авторського права, Аокладне визначення їх складу та Аинаміки $€$ пріоритетними завАаннями держави.

ЗапроваАження чинного Цивільного кодексу України (Аалі - ЦК) розблокувало можливість вкмючення суб'єктивного авторського права Ао складу відумерлої спадщини, тобто, іншими словами, Аопускається правонаступництво, зокрема посмертне. Так, наприклаА, коли автор не має спадкоємців ані за заповітом, ані за законом; або коли потенційні спадкоємці не прийняли спадщини чи віАмовилися віА її прийняття; або ж коли вони усунені віА права на спадкування, майно визнається віАумерлою спадщиною і переходить Ао територіальної громади в поряАку сингулярного правонаступництва (ст. 1277 ЦК), хоча раніше, згіАно зі ст. 555 ЦК УРСР 1963 року, відумерлу спадщину набувала держава. Здійснивши таку заміну, законодавець, утім, не надав АоклаАного врегулювання особливостей набуття та зАійснення територіальною громаАою прав та обов'язків, що входять Ао склаАу такої спаАщини, як і не врахував віАсутності реального Аос-
віАу й можливостей територіальної громади щодо управління ї̈ специфічними складовими.

Ця проблема перебуває в прямому взаємозв'язку з питанням Аостатності чи недостатності правосуб'єктності територіальної громади, щоб самостійно заійснювати авторські права, набуті в складі відумерлої спадщини, оскільки ефективність заійснення та захисту авторського права іншими (крім автора) учасниками цивільних правовіАносин значною мірою залежить віА компетенції, обсягу та специфіки їхньої правосуб'єктноcтi.

Через віАсутність АосвіАу, Аієвих важелів і механізмів територіальні громади вкрай неохоче набувають нового АосвіАу управління та розпоряАження авторськими правами, надаючи перевагу преАметам матеріального світу, що мають очевидну економічну вигоду. Таким чином, виникають сумніви щодо Аоречності наАання схвальної відповіді на поставлене питання.

Стан АосліАження теми. Зазначена проблематика часто мишається поза увагою українських науковців. Протягом останніх років вітчизняними вченими виконано немало ґрунтовних АосліАжень майнових прав інтелектуальної власності в цілому й авторського права зокрема, оАнак якщо в цих роботах і приАіляється увага посмертному правонаступництву, то тільки в аспекті спаАкування [1; 15]. Натомість внесок у АосліАження цієї проблематики зробили праці $Є$. Рябоконя [7; 8], Є. Фесенко [10], Г. Чурпіти [11] та інших науковців, які при вивченні інституту відумерлості спаАщини розглянули окремі аспекти існування авторських прав у її склаАі. При цьому Аоцільність 
заміни держави територіа^ьною громадою поставили піА сумнів лише окремі вітчизняні науковці.

Метою статті $€$ АосліАження системних проблем інституту відумерлої спадщини в Україні, що пов'язані з визначенням територіальної громади як суб'єкта цих правовідносин, а також вивчення специфіки набуття і здійснення авторських прав у складі відумерлої спадщини.

ВикиаА основного матеріалу АосліАження 3 повним обґрунтуванням отриманих наукових результатів. Особлива природа авторського права виражається передусім у тому, що Аля його виникнення не має жодного значення ані факт його реєстрації (ст. 11 Закону України «Про авторське право і суміжні права") (далі - Закон), ані факт оприлюднення твору. У відносинах посмертного правонаступництва такі особливості, між іншим, $€$ факторами, що зАатні значно усклаАнити їх уже на самому етапі виникнення.

У результаті кодифікації сучасного цивільного законодавства України інститут відумерлої спаАщини зазнав кардинальних змін: змінено як зміст такого правонаступництва, так і його суб'єктний і навіть об'єктний склаАи. Ці зміни частково вирішили наявні на час прийняття ЦК проблеми, однак також додали нових, не менш суттєвих.

Передусім запровадження чинного ЦК розблокувало можливість включення суб'єктивного авторського права Ао склаАу віАумерлої спаАщини. Так, на віАміну віА радянської чи Аоревомюційної Аоби, чинне цивільне законодавство тепер жодним чином не обмежує територіальну громаду в можливості набути в складі відумер^ої спадщини сереА іншого й авторські права померлого, що стало безпрецедентним кроком Аля українського права. А^я порівняння: згідно із законом Російської імперії «Про авторське право" віА 20 березня 1911 року, авторські права щодо творів, чий автор помер без спадкоємців, виокремлювалися з-поміж виморочної (віАумер^ої) спадщини, тобто не успадковувалися державою, а переходили в суспільне надбання. Після приходу в Україну радянської влади така пряма вказівка на певний час зникла із законодавства: ані Цивільний кодекс УСРР 1922 року, ані Закон УРСР «Про авторське право» 1929 року прямо не вказували на перехід у суспільне надбання твору, чий автор не має спалкоємців, хоча на практиці віАсутність останніх означала відсутність суб'єктів авторського права, а відтак, його фактичний перехід у "надбання держави". Авторське право припинялося навіть тоді, коли Ао спливу віАповіАного строку помер спадкоємець автора (ст. 11 Основ авторського права віА 1928 року). Також Основи авторського права 1925 і 1928 років надавали Аержаві широкі повноваження 3 націоналізації авторського права живих і померлих авторів на власний розсуд. У такому разі здійснення й розпоряАження ними зАійснювалося Наркомом освіти. Відновлення прямої вказівки про виключення авторських прав зі складу відумерлої спаАщини та перехіА твору, чий автор не мишив спадкоємців, у суспільне надбання відбулися з прийняттям ЦК УРСР у 1963 році: припинення авторських прав у такому разі регламентувалося ст. 555 ЦК yPCP.

Поза сумнівом, такий підхіА мав мало спільного із сутністю авторських прав і нормальним розвитком правовідносин у цій сфері, водночас цілком віАповіАав Аухові радянського періоду з притаманним йому усебічним контролем за інтелектуальною Аіяльністю громадян. Тож при розробці чинного ЦК України віА цього положення відмовилися, тепер авторське право може переходити до територіальної громаАи на загальних піАставах.

Говорячи про авторські права, не можна не зазначити, що традиційні об'єкти цивільних прав, що мають чітко виражену матеріальну ("тілесну") форму, як-от нерухомість та інше цінне майно, $€$ зазвичай більш "помітними" Аля правонаступників. Це пов'язано з ускладненими процедурами набуття такого майна, напрацьованою законодавчою та правозастосовною базою, та, безумовно, не варто також недооцінювати фактор економічної вигоди при набутті таких об'єктів. Що ж стосується суб'єктивного авторського права, то тут склалася Аіаметрально протилежна ситуація. Ураховуючи те що воно виникає незалежно віА Аотримання будь-яких формальностей, спадкоємці померлого можуть навіть не бути обізнаними про наявність у нього авторських прав. Якщо віАносно близькі Ао спаАкодавця особи часто не володіють такою інформацією, то орган місцевого самоврядування, який звертається Ао суду із заявою про визнання відумерлою спаАщини, тим паче не може знати про наявність у померлого авторських прав.

Крім того, ці правовіАносини значно усклаАнені тим, що територіальна громада набуває відумерлу спадщину не автоматично, а за заявою в порядку окремого провадження. Згінно зі ст. 1277 ЦК, набуття відумерлої спадщини - не обов'язок територіальної громади, а ії право, яке вона використовує Аосить Аовільно, будучи зацікавленою переважно в набутті предметів 
матеріального світу. Якщо ж спадщина з певних причин не являє собою економічний інтерес Аля територіальної громади, правонаступництво просто не відбувається, а юридична й фактична доля спадкової маси ризикує роками бути невизначеною. I при цьому, незважаючи на смерть автора, об'єкти авторських прав не втрачають своєї потенційної цінності насампереА Аля суспільства, тож в окремих громадян цілком може виникати потреба в такому використанні результату Аіяльності померлого автора, Аля якого необхінне отримання відповідного Аозволу нового суб'єкта авторського права. Якщо ніхто не набув відумерлу спадщину, до складу якого належать авторські права, то отримати такий Аозвіл також буде неможливим.

Відповідно Ао ст. 335 Цивільного процесуального кодексу України (Аалі - ЦПК), заява органу місцевого самоврядування має містити сереА іншого вказівку на майно, що становить спаАщину, і докази, які свідчать про належність цього майна спадкодавцю. Свідомо чи ні, але зазвичай органи місцевого самоврядування не зазначають про наявність у померлого прав інтелектуальної власності [5; 6], звертаючись натомість Ао суду з метою набуття нерухомості, окремого рухомого майна, речей-результатів інтелектуальної творчості (хоча, за ч. 1 ст. 419 ЦК, право інте^ектуальної власності та право власності на річ не залежать одне віА одного; а об'єктом наступництва є не самі матеріальні об'єкти, а права й обов'язки померлого). Безумовно, таке майно має очевидну матеріальну цінність порівняно 3, наприклаА, суб'єктивним авторським правом.

Утім реєстрація авторського права також не завжАи Аає змогу уникнути низки проблем у правонаступництві. Нині в Україні наявні Ава окремі реєстри - Аержавний реєстр свідоцтв про реєстрацію авторських прав на твір і Аержавний реєстр Аоговорів, які стосуються права автора на твір. ОАнак, як слушно зазначає І. Якубівський, окрім Аоговору, існують також інші похідні піАстави набуття майнових авторських прав (наприклаА, спаАкування), але з незрозумілих причин нині функціонує реєстрація мише однієї з похіАних підстав набуття майнових авторських прав [15, с. 153]. На практиці існування Авох окремих реєстрів призводить до усклаАнення самого процесу Аоказування належності авторських прав тому чи іншому суб'єкту, що за наявності спору покладає великий тягар на сторону, чиї права й без того порушені. Не виключаємо й можливість так званої "подвійної» реєстрації одних і тих самих прав у Авох реєстрах, коли реально авторське право вже було відчужене. Перелік подібних проблем, спричинених відсутністю одного уніфікованого реєстру, є наАзвичайно Аовгим і заслуговує на окреме вивчення.

Обізнаність учасників цивільних правовідносин про обсяг спадкової маси також часом далека від бажаного: уявлення про об'єктний склаА спаАщини Аосить часто обмежуються найбільш економічно вагомими об'єктами матеріального світу. Сам правовласник, складаючи заповіт щодо конкретного майна, також Аалеко не завжди може усвідомлювати потребу визначити в ньому Аолю авторських прав. За відсутності спадкоємців за законом такі права можуть бути визнані відумерлою спадщиною.

Тим не менше законодавець Аосить однозначно вирішує проблему подібної "вибірковості": згіАно зі ст. 338 ЦПК, суА, установивши, що спаАкоємці за заповітом і за законом відсутні, або спадкоємці усунені віА права на спадкування, або спадкоємці не прийняли спаАщину чи віАмовилися віА ії̈ прийняття, ухвалює рішення про визнання спаАщини відумерлою та про передачу ії територіальній громаді віАповіАно до закону.

Справді, віАповіАно Ао положень ст. ст. 1218 і 1277 ЦК, спалковий актив за рішенням суду повною мірою переходить до територіальної громади незалежно віА обізнаності щодо наявності в померлого авторського права. Інше питання, щоправда, полягає в тому, що безсуб'єктність у такому разі усувається, але проблема ефективного зАійснення таких прав, що, як зазначалося, $€$ однією із цілей інституту відумерлості, залишається невирішеною.

Що стосується суб'єктного склаАу правонаступництва щодо відумерлої спаАщини, то усталений піАхіА Ао визначення Аержави таким правонаступником потрапив піА жорна спроб віАмовитися віА радянського "Аержавоцентризму", який у цивільних правовіАносинах виражався насамперед у закріпленні за державою основних знарядь і засобів виробництва. Утім огляА інституту віАумерлої спадщини в історичній ретроспективі свідчить про те, що таке положення не прояв радянського етатизму, а лише продовження тривалої практики переходу відумерлої спадщини Ао держави, витоки якої сягають ще давньоруських часів, коли відумерла спадщина переходила у власність князя [9, с. 164]. Таке правонаступництво Аістало свого розвитку й за литовсько-польської Аоби, коли відумерщина переходила у власність сюзерена, і в часи існування Гетьманщини, 
коли така спадщина спрямовувалася на користь скарбниці [2, с. 533]. Після встановлення панування Російської імперії виморочне майно набувала, крім деяких винятків, саме держава. Це правило успалкувало й радянське законодавство (ст. 433 ЦК УРСР 1922 року).

Такий піАхіА і нині зберігся в багатьох країнах світу, зокрема у Франції (ст. 768 ФЦК), Німеччині (пар. 1936 НЦУ), Росії (ст. 1151 ЦК РФ), Білорусі (п.5ст.1054ЦК), Італії(ст.586ЦК), Чехії(§1634ЦК), ヘитві (ст. 5.62 ЦК), Аатвії (ст. 416 ЦК), Австрії (§ 760 ЦК), Швейцарії (ст. 466 ЦК), Казахстані (п. 5 ст. 1057 ЦК), ТаАжикистані (п. 5 ст. 1152 ЦК), а також США, Великій Британії тощо саме держава набуває відумерлу спадщину.

Замінивши державу територіальною громаАою, законодавець так і не надав їй практичних механізмів Аля зАійснення ефективного управАіння набутим майном, попри те що саме захист та ефективне управління, а не проста ліквідація безсу'єктності є основними завданнями інституту відмерлої спадщини. Тому, на наш погляА, така заміна базована більше на ілеологічних мотивах і не засновувалася на реальних практичних потребах і цілях інституту відумерлої спадщини.

Варто, тим не менше, зазначити, що формально територіальна громада Аосі не зазначена як потенційний суб'єкт авторського права ані в ст. 435 ЦК, ані в ст. 7 Закону. Так, ст. 435 ЦК вказує, що суб'єктами авторського права є автори, інші фізичні та юридичні особи, які набули прав на твори віАповіАно Ао Аоговору або закону. Стаття 7 Закону також зазначає, що Ао таких суб'єктів, крім авторів, належать їхні спаАкоємці й особи, яким автори чи їхні спаАкоємці передали свої авторські майнові права. Так само ч. 2 ст. 29 цього нормативно-правового акта поширює право захищати авторство на твір і протидіяти перекрученню, спотворенню чи іншій зміні твору, а також іншим посяганням на твір, небезпечним Аля честі й репутації автора, тільки на спадкоємців.

Подібне формулювання повторюється й у віАносно нових нормативно-правових актах. Так, Закон України «Про ефективне управління майновими правами правовласників у сфері авторського права і (або) суміжних прав" (2018) урегульовує колективне управління майновими правами суб'єктів авторського права й (або) суміжних прав, яке може зАійснювати організація колективного управління (ст. 1 цього Закону). Відповідно до цього положення, така організація може бути заснована виключно правовлас- никами - суб'єктами авторського права або суміжного права, іншою особою, яка на підставі Аоговору із суб'єктом авторського права й (або) суміжних прав чи згідно із законом має право на отримання частки доходу віА прав.

На наш погляА, у такому разі варто застосувати розширювальне тлумачення цих норм: передача означає в тому числі перехід у силу закону, і правонаступником може бути не тільки особа, а учасник цивільних правовіАносин у цілому.

Видається, що цілком реальна можливість територіальної громади набувати авторські права внаслідок особливого посмертного правонаступництва Аосі лишається неочевидною не тільки Аля законодавця, а й навіть Аля самої територіальної громаАи. її участь у відносинах відумерлості явище саме по собі нове Аля вітчизняної правової системи, як і практика включення до такої спаАщини авторських прав. За таких обставин очікування АоклаАного преАметного врегулювання цих віАносин у законодавстві є Аосить виправданими, адже воно зАатне виконати головне завдання в цій сфері - забезпечити непорушність і захищеність прав автора навіть після його смерті.

Низька увага Ао проблеми безсуб'єктності авторських прав викликана передусім недостатнім рівнем правосвідомості українських громадян у сфері права інтелектуальної власності, поширеністю піратства, плагіату, підроблення тощо. Захищеність прав інтелектуальної власності $€$ питанням загальнодержавного масштабу, позаяк віА цього залежить економічний потенціал Аержави, рівень залучення інвестицій, технічний прогрес. Тому охорона авторських прав, які втратили свого носія, вимагає розробки єАиної державної політики, чітких і компетентних піАходів Ао її реалізації. НавряА чи можна говорити про наявність Аля цього віАповіАної правосуб'єктності й Аосвіду в територіальних громад і їх органів, у цьому аспекті держава має незрівнянно більше повноважень і важелів впливу не тільки щодо сфери інтелектуальної власності, а й щодо решти об'єктів, що можуть бути склаАником спаАщини: виокремлення якогось оАного виАу об'єктів 3-поміж іншого спаАкового майна та їх окремий перехіА Ао Аержави як правонаступника у відумерлій спаАщині суперечило б фундаментальним положенням спадкового права та не є Аоцільним ані в теоретичній, ані в практичній площині.

Аержавна політика порівняно з політичною Аіяльністю інших інститутів політичної участі виражає загальні інтереси населення, а також $€$ концентрованим їх відображенням. А^я вико- 
нання цього призначення держава утворює віАповіАну систему органів влаАи, які зАійснюють вироблення й реалізацію державної політики. Тому питання управління авторськими правами в складі відумерлої спадщини має здійснюватися не територіальною громадою, а компетентними органів держави, що зАійснюють Аержавну політику у відповідній сфері. Це Аасть змогу не просто уникнути безсуб'єктності, а забезпечити ефективний захист майнових і немайнових прав автора, а також потенційну цінність твору Аля суспільства. При переході ж авторських прав до територіальної громади практично неможливо говорити про один централізований піАхіА Ао врегулювання цієї сфери.

Тому ми переконані, що держава, маючи незрівнянно більший обсяг правосуб'єктності, а також ширший спектр механізмів і "важелів" впливу, зокрема можливостей щодо створення спеціалізованих органів та установ, є більш ефективним правонаступником у відумерлій спадщині.

Ми, утім, уважаємо також неправильним наАмірно переоцінювати їі можливості щодо зАійснення всіх специфічних прав, що теоретично можуть опинитися в складі відумерлої спадщини. Як і територіальна громада, держава зазвичай не має віАповіАного АосвіАу чи компетентного розуміння ефективності зАійснення таких прав, аАже управління всім обсягом відумерлої спаАщини зазвичай зАійснюється ЄАиним органом без подальшої Аиференціації повноважень і без урахування особливостей тих чи інших об'єктів у складі відумерлої спадщини.

Тому перевага держави як правонаступника у відумерлій спадщині полягає в потенційно необмежених можливостях з управління таким майном, у зАатності зАійснення його розумного розпоАілу між окремими установами й організаціями, аАже уніфікувати піАхіА Ао всіх об'єктів означає не врахувати всієї різноманітності не тільки прав інтелектуальної власності, а й інших потенційних складників спадщини. Тому необхідно надати державі можливість спеціально наділяти компетентні Аержавні органи відповідними повноваженнями щодо його зАійснення та захисту.

Так, наприклаА, окремі Аержави прямо визначили, що авторських прав у складі відумерлої спадщини відразу набуває компетентний орган: у ст. 49 Закону Аитви "Про авторське право" встановлено, що за відсутності спадкоємців за законом чи заповітом захист особистих немайнових прав автора зАійснюється уповноваженим органом Аержавної влаАи (Міністерство культури ^итви). Стаття 150 Закону Італії «Про авторське право" вказує, що в разі, коли автор не має спадкоємців, його майнові права покладаються на Національний орган 3 питань страхування та Аопомоги художникам і скульпторам. ВАалим також $€$ піАхіА Чехії: подальша Аоля авторських прав, успадкованих державою за заповітом або набутих нею в складі відумерлої спадщини, спеціально визначена в ч. 2 ст. 26 Закону Чеської Республіки "Про авторське право». В обох зазначених випадках авторські майнові права віА свого імені зАійснює Аержавний фонд культури Чеської Республіки. Виняток становлять авторські права щодо аудіовізуальних робіт: у цьому разі право зАійснення прав належить Аержавному фонду Чеської Республіки з підтримки та розвитку чеського кінематографу. Прибуток набувається цими фонаами й, віАповіАно, спрямовується на потреби культури.

В Україні в разі введення подібної практики можливе надання відповідних повноважень юриАичній особі, що зАійснює Аіяльність не тільки у сфері культури, а й галузі економічного розвитку Аержави. Так, із 28 жовтня 2020 року Українське агентство з авторських та суміжних прав (Аалі УААСП), засноване в 1926 році з метою забезпечення колективного управління авторськими та суміжними правами правовласників, перебуває в стані припинення. Згаданим нами вище Законом України "Про ефективне управління майновими правами правовласників у сфері авторського права і (або) суміжних прав" запущено реформу у сфері колективного управління, передбачивши роздержавлення УААСП і створення громадської організації, яка стане його правонаступником. Нині відсутні офіційні відомості про правонаступництво, хоча Мінекономрозвитку вже розмістило оголошення на своєму офіційному веб-сайті з пропозицією щодо заміни УААСП громаАською організацією “СпівАружність авторів України" як сторони Аоговору управління майновими авторськими правами [4].

Аумка про необхінність передачі авторських прав у складі відумерлої спадщини спеціалізованим установам уже висловлювалася, зокрема, ученим Є. Рябоконем, який, уважаючи за необхідне повернути державі статус спадкового правонаступника у відумерлій спадщині, зауважує, що держава в силу своєї природи також не зАатна належним чином управляти всіма правами й обов'язками померлого, зокрема авторськими правами. Відтак, на Аумку науковця, варто було $б$ передати повноваження спеціально створеним 
організаціям, зокрема тим, які уповноважені зАійснювати колективне управління авторськими правами [8, с. 247]. Обґрунтовуючи свою позицію, автор посилається також і на АосвіА Аоревомюційного законодавства [7, с. 307].

Справді, попри те що Аореволюційне законодавство однозначно не розгляАало авторське право як складник відумерлої спаАщини, Аиференціація інших об'єктів останньої має свої прецеденти. Законодавству Російської імперії (ст. ст.. 1162, 1163, 1263 т. Х, ч. 1 Зводу законів) було відомо Ава принципи визначення набувача такої спаАщини: за загальним правилом, відумерла спадщина набувалася Аержавою, однак були й виняткові випаАки, визначені, зокрема, ст. ст. 1168, 1169, 1172, 1172.1 і 1172.2 Зводу законів, коли спадщина переходила у власність окремих установ. У таких виняткових випадках учений Г. Шершеневич убачав конкуренцію майнових прав держави та цих установ [14, с. 770].

НаприклаА, рухоме майно, яке лишалося після смерті Ауховних Аіячів, переходило на користь Ауховного відомства. Якщо таке майно належало померлим членам університетів, чиновникам освітнього управління Міністерства народної освіти, а також членам Імператорської академії мистецтв, то така спадщина переходила у власність тих закладів, де працював спадкодавець. При цьому Ао установ переходила спадкова маса в цілому, а не тільки авторські права на результати їхньої творчості.

Історія набуття навчальними закладами майна викладачів як на підставі заповіту, так і в порядку визнання спадщини відумерлою, є багатою. НаприклаА, А. Осинський - учений-богослов XIX століття, який володів великою бібліотекою та власним Аоробком наукових праць і переклаАів. Учений помер, не залишивши ані заповіту, ані спалкоємців, і праці були передані Київському університетові, який був правонаступником Кременецького ^іцею, Ае працював науковець [3, с. 73].

Таким чином, ми переконані, що набуття державою авторських прав як складника відумерлої
спаАщини має зАійснюватися через їх перехіА у власність органу, що реалізує державну політику у сфері авторського права, а цей орган, у свою чергу, повинен мати можливість розподілити окремі об'єкти між установами й організаціями у випаАках, коли це є Аоцільним. При цьому ми Аопускаємо, що такий розподіл необов'язково має стосуватися юридичних осіб публічного права: окремі юридичні особи приватного права, прямо пов'язані з Аіяльністю померлого, будуть набагато ефективніше зАійснювати ці права на користь суспільству.

Висновки з АосліАження та перспективи подальших розвідок у цьому напрямі. Очевидна перевага Аержави як правонаступника у відумерлій спадщині полягає в потенційно необмежених можливостях з управління таким майном, у зАатності зАійснення його розумного розподілу між окремими установами й організаціями. При цьому ми переконані, що держава буде більш ефективним правонаступником не тільки в правах інтелектуальної власності, а й у відумерлій спадщині в цілому. Тому необхідно Аати Аержаві можливість спеціально наділяти компетентні Аержавні органи відповіАними повноваженнями щодо зАійснення та захисту окремих прав.

Що стосується авторських прав, то особливості правонаступництва в авторському праві в складі відумерлої спадщини в межах Закону України "Про авторське право і суміжні права", як це практикується в зарубіжному законодавстві, однак таке визначення матиме сенс, якщо норма міститиме сереА іншого відповідну вказівку на уповноважений орган.

Вітчизняному законодавцю ще належить подолати значний шлях Ао врегулювання АосліАженої нами проблематики. ПерегляА наявного досвіАу, продукування актуальних піАходів і розумне запозичення інститутів іноземного права Аасть змогу адаптувати законодавство до викликів сьогодення та нарешті подолати нігілізм, що панує у сфері інтелектуальної в^асності.

\section{NITEPATУPA:}

1. Бєльтюкова Є.М. Правове регулювання наступництва майнових прав інтелектуальної власності за цивільним законодавством України : дис. ... канд. юрид. наук : 12.00.03. Одеса, 2019. 183 с.

2. Гурбик. А.О. Відумерщина. Енциклопедія історії України : у 10 т. / Інститут історії України НАН України. Київ : Наукова думка, 2003. Т. 1 : А - В. 688 с. : іл.

3. Мяскова Т. Бібліотека Імператорського університету Св. Володимира: з історії комплектування (1834-1927рp.). Національна бібліотека України ім. В.І. Вернадського. Київ, 2005. 184 с.

4. Оголошення щодо звернення до правовласників та організацій, з якими ДО «УААСП» були укладені договори 3 пропозицією щодо заміни сторони договору. URL: http://surl.li/osvy.

5. Рішення Верховинського районного суду Івано-Франківської області від 30 листопада 2018 року у справі № 340/478/18. URL: http://reyestr.court.gov.ua/Review/78363830. 
6. Рішення від Ленінського районного суду м. Вінниці від 21 березня 2012 року у справі № 212/1571/2012. URL: http://reyestr.court.gov.ua/Review/22488620.

7. Рябоконь Е.А. Правопреемство в выморочном имуществе по гражданскому законодательству Украины. Studia Iuridica. Warszawa, 2015. Tom 61. Miscellanea. S. 299-308.

8. Рябоконь Є.О. Розвиток доктрини відумерлості (виморочності) спадкового майна. Сучасні тенденції розвитку спадкового права (порівняльно-правове дослідження) : монографія / відп. ред. академік НАПрН України В.В. Луць. Київ : Науково-дослідний інститут приватного права і підприємництва імені академіка Ф.Г. Бурчака НАПрН України, 2015. С. $224-247$.

9. Українська мала енциклопедія : у 16 кн. : у 8 т. / проф. Є. Онацький. Накладом Адміністратури УАПЦ в Аргентині. Буенос-Айрес, 1958. Т. 1. Кн. ІІ : Літери В - Г. С. 163-164.

10. Фесенко Є.В. Деякі питання спадкування авторських прав на твір, створений у співавторстві. Право.иа. 2018 . № 2. C. 149-156. URL: http://nbuv.gov.ua/UJRN/pravo_2018_2_25.

11. Чупрій Д.Ю. Особливості правонаступництва в авторських правах у складі відумерлої спадщини. Юридичний науковий електронний журнал. 2020. № 2. C. 79-85. URL: http://lsej.org.ua/1_2020/21.pdf.

12. Чупрій Д.Ю. Управління авторськими правами, що опинилися без спадкоємців, за зарубіжним законодавством. Право і суспільство. 3021. № 3.

13. Чурпіта Г.В. Спадкування права інтелектуальної власності / Актуальні проблеми спадкового права : навчальний посібник / за заг. ред. проф. Ю.О. Заіки, ст. наук. спів. О.О. Лов'яка. Київ : КНТ, ЦУЛ, 2014. С. 296-303.

14. Шершеневич Г.Ф. Учебник русского гражданского права. Москва : Издание Бр. Башмаковых, 1911. 850 с.

15. Якубівський I.Є. Проблеми набуття, здійснення та захисту майнових прав інтелектуальної власності в Україні : дис. ... докт. юрид. наук : 12.00.03. Львів, 2019. 519 с.

\section{Чупрій Аіана Юріївна \\ ОКРЕМІ ПРОБАЕМИ СУБ'ЄКТНОГО СКАААУ ПРАВОНАСТУПНИЦТВА В АВТОРСЬКИХ ПРАВАХ У СКАААІ ВІАУМЕРАОї СПААЩИНИ}

Стаття присвячена теоретичним і практичним проблемам інституту відумерлої спадщини за українським законодавством, яку вже майже Авадцять років може набувати територіальна громада. Центральне місце в досліАженні займають особливості набуття й подальшого здійснення нею авторських прав у складі такої спадщини, позаяк ці об'єкти вирізняються насампереА своєю потенційною значущістю не тільки Аля окремих суб'єктів, а й Аля суспільства в цілому, незважаючи на смерть автора. Попри це, практика набуття територіальною громадою Аосі лишається біАною у зв'язку із, зокрема, Аосить поверховим нормативним урегулюванням цього питання, низькою культурою використання результатів чужої інтелектуальної творчості, необізнаністю щодо складу відумерлої спадщини, а також браком досвіду та механізмів щодо управління такими специфічними правами. Зазначене призводить Ао безсуб'єктності й унеможливлює законне використання громаАянами результатів творчості автора, який помер без спадкоємців.

У статті зазначається, що ефективність такого управління перебуває в прямій залежності віА обсягу та специфіки правосуб'єктності, компетенції та наявності віАповіАного досвіду в правонаступника. У межах АосліАження проведено огляд історії інституту відумерлої спадщини в Україні та проаналізовано законодавство деяких зарубіжних країн, на піАставі чого автор Аійшов висновку про Аоцільність повернення Ао практики набуття відумерлої спадщини державою. У роботі обґрунтовується, що саме держава буде більш ефективним правонаступником не тільки в правах інтелектуальної власності, а й у відумерлій спадщині в цілому. Перевага держави як правонаступника у відумерлій спадщині полягає в потенційно необмежених можливостях з управління таким майном, можливості централізованої реалізації державної політики у сфері інтелектуальної власності, а також у здатності зАійснення його розпоАілу між окремими установами й організаціями, тому необхіАно Аати державі можливість спеціально наділяти компетентні державні органи відповідними повноваженнями щодо здійснення та захисту таких прав.

Автор пропонує окремо врегулювати особливості такого правонаступництва в межах Закону України "Про авторське право і суміжні права", як це практикується в зарубіжному законодавстві, і визначити орган, який буде наділений повноваженнями з управління таким специфічним складником відумерлої спадщини.

Киючові слова: відумерла спадщина, авторські права, сингулярне правонаступництво, територіальна громаАа.

\section{Chuprii Diana}

\section{THE PROBLEM OF LOCAL COMMUNITY'S ESCHEATAGE OF THE COPYRIGHT UNDER UKRAINIAN LAW}

These sciencific papers are devoted to succession in copyrights as a part of escheat law. Central to this study are the features of the acquisition and subsequent exercise of copyright by the local community, as these objects differ from other possible components of the extinct heritage primarily by their potential significance not only for individuals but also for society despite death of the author. The author highlights a number of the actual problems in Ukrainian law concerning the acquisition of the escheated copyrights by the local community and analyzes the foreign experience for seeking a better resolution of these issues.

The practice of acquisition by the local community still remains poor due to, in particular, rather superficial regulation of this issue, low culture of using the results of other people's intellectual creativity, low awareness 
of the extinct heritage, and lack of experience and mechanisms for managing such specific rights. This makes it impossible for citizens to legally use the results of the work of the author, who died without heirs.

The copyrights are the specific object that needs a protection because of their great value for social relations and development of the human civilization, and the absence of heirs threatens the stability of the legal relations and the institute of succession. Art. 1277 of the Civil Code of Ukraine provides the standart of escheating by local community in general, but specifics of copyright and their management wasn't taken into account.

The effective protection of copyright depends on the legal personality of the succesor and his competence in this field. The author argues that the local community is not an effective successor of copyrights because of the absence of any real mechanisms of managing. Moreover, for twenty years of the existence of the local community's ability to become the owner of the escheated property, there are no precedents of initiating this procedure concerning copyrights. The local community hasn't got any experience in this field, and it is interested in the acquisition of real estate or results of intellectual creativity more than in owning and managing copyrights.

The author proposes to regulate the features of such succession within the Law of Ukraine "On Copyright and Related Rights", as it is practiced in foreign law, and determine the body that will be empowered to manage such a specific component of the deceased heritage.

Key words: the escheat law, the copyrights, the succession, the singular succession, inheritance. 